\title{
REKONSTRUKSI HUBUNGAN KOMITE SEKOLAH DAN SEKOLAH UPAYA MENINGKATKAN MUTU PENDIDIKAN ERA PENDIDIKAN ABAD KE-21
}

\author{
Abdul Majir \\ Sekolah Tinggi Keguruan dan Ilmu Pendidikan \\ Santu Paulus Ruteng Flores-NTT \\ Abdulmajir@gmail.com
}

\begin{abstract}
Abstrak
Perubahan paradigma dari sentralisasi ke desentralisasi membuka peluang yang luas bagi masyarakat untuk dapat memainkan peran sebagai pemberi pertimbangan (advisory body), pendukung (supporting agency), pengontrol (controlling agency) dan mediator sesuai dengan semangat manajemen berbasis sekolah (school-based management), Diharapkan Melalui rekonstruksi hubungan masyarakat dengan sekolah atau kerja sama stakeholder pendidikan mampu meningkatkan mutu pendidikan dan mempersiakan serta mengantisipasi tantangan pendidikan abad ke 21 saat ini. Dimana arus globalisasi tidak dibatas ruang dan waktu akan mempengaruhi seluruh sektor kehindupan bangsa dan Negara. Bagaimana penerapan peran komite sekolah di Sekolah? Bagaimana sinergitas Komite Sekolah dengan sekolah selama ini? Bagaimana kerjasama stakeholder pendidikan era pendidikan abad ke- 21 yang sarat dengan persaingan sumber daya manusia? Tulisan akan mengkaji peran komite sekolah dan realita kinerja selama ini serta bagaimana seharusnya yang dilakukan oleh stakeholder pendidikan mempersiapkan dan mengantisipasi persaingan pendidikan abad ke 21 saat ini.
\end{abstract}

Kata kunci: Rekonstruksi Hubungan, komite sekolah, mutu pendidikan dan pendidikan abad ke-21.

\section{PENDAHULUAN}

Perubahan paradigma pemerintahan dari sentralisasi ke desentralisasi membawa nuansa baru bagi masyarakat sekolah untuk dapat berpartisipasi aktif dalam pengelolaan pendidikan. Untuk mewujudkan partisipasi aktif masyarakat dalam pengelolaan pendidikan pemerintah telah menetapkan Undang-Undang Nomor 25 Tahun 1999 tentang Program Pembangunan Nasional (PROPENAS) 2000-2004 dan Undang-Undang Nomor
32 Tahun 2004 tentang otonomi daerah, untuk memperkuat peran dan fungsi dewan pendidikan dan komite sekolah. Otonomi daerah memberi ruang yang luas dalam pengelolaan dan penyelenggaraan pendidikan. Dimana pemerintah daerah sebagai pemegang kekuasaan tertinggi di daerah dapat mengakomodir pandangan, aspirasi dan menggali potensi daerah masing-masing untuk terciptanya demokratisasi pendidikan. Pemerintah daerah hendaknya mendorong tumbuhnya 
perhatian dan komitmen masyarakat terhadap penyelenggaraan pendidikan yang bermutu dengan melakukan kerjasama dengan masyarakat, baik perorangan maupun organisasi, dunia usaha dan dunia industry DU/DI). Selain itu pemerintah daerah juga dapat memberi masukan, pertimbangan dan rekomendasi kepada pemerintah pusat mengenai kebijakan dan program pendidikan, kriteria tenaga kependidikan, khususnya guru dan kepala sekolah, dan fasilitas pendidikan. Sehingga di daerah dapat melakukan pengembangan dan peningkatkan kualitas in put, proses dan output pendidikan yang berwawasan luas, bersikap rasional, dan memiliki kompetensi -sesuai dengan kebutuhan masyarakat di sekitar lembaga pendidikan.

Belakangan ini Ada opini di kalangan masyarakat luas bahwa Komite Sekolah belum dapat menjalankan peran dan fungsinya secara optimal seperti yang diharapkan. Bahkan, ada beberapa di antaranya yang keberadaannya menimbulkan dampak kontra produktif, karena telah menimbulkan citra negatifnya sendiri. Realitas lainnya terkait keberadaan Komite Sekolah di lapangan menunjukkan bahwa Komite Sekolah yang diharapkan dapat mendorong partisipasi aktif masyarakat dalam penyelenggaraan pendidikan juga belum nyata, antara Komite Sekolah dengan pihak sekolah (terutama Kepala Sekolah) sering terjadi "ketegangan", atau belum terjalin prinsip kemitraan dengan baik.

Berpijak dari fenomena sebagaimana diuraikan di atas, dikaitkan dengan penyelenggaraan pendidikan, maka melalui

rekonstruksi peran komite sekolah sebagai lembaga pendidikan tidak lagi menanggung sendiri beban untuk meningkatkan mutu pendidikan. Selama ini masyarakat selalu dualisme menilai kinerja guru. Guru dipuji kalau anaknya prestasi dan guru dicemooh kalau anaknya tidak memproleh hasil belajar yang memuaskan. Orangtua lepas tanggung jawab dengan mutu pendidikan di sekolah.

Artikel ini akan mengkaji rekonstruksi peran komite sekolah, sinergitas Komite Sekolah dengan sekolah dan kerjasama stakeholder pendidikan era pendidikan abad ke21yang sarat dengan persaingan sumber daya manusia.

\section{KOMITE SEKOLAH}

Ditinjau dari perspektif sejarah persekolahan pada tingkat SD, SLTP, dan SMU/SMK atau sederajat di Indonesia, masyarakat sekolah (orang tua siswa), telah banyak membantu penyelenggaraan pendidikan. Sebelum tahun 1974 masyarakat di lingkungan masing-masing sekolah telah membentuk Persatuan Orang Tua 
Murid dan Guru (POMG). Seiring perjalan waktu perkembangan pendidikan semakin meningkat, tahun 1974 POMG diganti dengan Badan Pembantu Penyelenggara Pendidikan (BP3).Setelah terjadi reformasi tahun 1998-2002, BP3 berubah nama menjadi Komite Sekolah yang ditetapkan melalui SK Mendiknas Nomor 044/U/2002. Komite Sekolah adalah nama badan yang berkedudukan pada satu satuan pendidikan, baik jalur sekolah maupun luar sekolah, atau beberapa satuan pendidikan yang sama di satu kompleks yang sama.

Pada saat era Manajemen Berbasis Sekolah (MBS) perlu dibenahi selaras dengan tuntutan perubahan yang dilandasi kesepakatan, komitmen, kesadaran, dan kesiapan membangun budaya baru dan profesionalisme dalam mewujudkan "Masyarakat Sekolah" yang memiliki loyalitas pada peningkatan mutu sekolah. Untuk terciptanya suatu masyarakat sekolah yang kompak dan sinergis. Komite Sekolah diharapkan dapat memacu usaha pemberdayaan masyarakat untuk meningkatkan mutu pendidikan, selaras dengan konsepsi partisipasi berbasis masyarakat

(community-based participation) dan manajemen berbasis sekolah (school-based management) yang kini tidak hanya menjadi wacana, tetapi telah mulai dilaksanakan di Indonesia.

Komite sekolah merupakan organisasi masyarakat pendidikan yang mempunyai komitmen dan loyalitas serta peduli terhadap peningkatan kualitas pendidikan di daerah. Komite sekolah dibentuk dan dikembangkan secara khas dan berakar dari budaya, demografis, ekologis, nilai kesepakatan, serta kepercayaan yang dibangun sesuai karakteristik daerah secara kolektif. Artinya, komite sekolah mengembangkan konsep yang berorientasi kepada pengguna (client model), berbagai kewenangan (power sharing and advocacy model) dan kemitraan (partnership model) yang difokuskan pada peningkatan mutu pelayanan pendidikan di daerah.

Terbentuknya komite sekolah pada setiap sekolah atau kelompok sekolah merupakan langkah penyebaran tanggung jawab dan kewenangan pengelolaan pendidikan sehingga perkembangan pendidikan bukan saja menjadi otoritas mutlak unsur internal sekolah di bawah komando kepala sekolah akan tetapi komite sekolah dapat berkontribusi untuk mendorong para tenaga pendidik dan kependidikan agar dapat bersama-sama dan berkonsentrasi memajukan pendidikan yang dikelolanya

\section{REKONSTRUKSI PERAN KOMITE SEKOLAH}

Komite Sekolah merupakan suatu organisasi masyarakat sekolah. Karena merupakan sebuah organisasi, maka komite sekolah memiliki peran dan 
fungsi yang sangat strategis sebagai wadah bagi masyarakt sekolah untuk menyalurkan aspirasi dan prakarsa masyarakat dalam melahirkan kebijakan operasional, dan menciptakan suasana dan kondisi transparan, akuntabel, dan demokratis dalam penyelenggaraan dan pelayanan pendidikan yang bermutu di sekolah. Adapun peran komite sekolah adalah: 1) Pemberi pertimbangan (advisory body) dalam penentuan dan pelaksanaan kebijakan pendidikan, 2) Pendukung (supporting agency), baik yang berwujud finansial, pemikiran maupun tenaga dalam penyelenggaraan pendidikan, 3) Pengontrol (controlling agency) dalam rangka transparansi dan akuntabilitas penyelenggaraan dan keluaran pendidikan, dan 4) Mediator antara pemerintah (eksekutif) dan Dewan Perwakilan Rakyat Daerah (legislatif) dengan masyarakat. Sedangkan Untuk menjalankan perannya itu, komite sekolah memiliki fungsi yaitu: 1) Mendorong tumbuhnya perhatian dan komitmen masyarakat terhadap penyelenggaraan pendidikan yang bermutu; 2) Melakukan kerja sama dengan masyarakat (perorangan/organisasi), pemerintah dan DPRD berkenaan dengan penyelenggaraan pendidikan yang bermutu; 3) Menampung dan menganalisis aspirasi, ide, tuntutan, dan berbagai kebutuhan pendidikan yang diajukan oleh masyarakat, 4) Mendorong orang tua dan masyarakat berpartisipasi dalam pendidikan, 5) Melakukan evaluasi dan pengawasan terhadap kebijakan, program, penyelenggaraan, dan keluaran pendidikan.

Selain peran dan fungsi komite sekolah yang di uraikan di atas, komite sekolah meperoleh tugas yaitu:

kebijakan dan program sekolah, Rencana Anggaran Pendapatan dan Belanja Sekolah/Rencana Kerja dan Anggaran Sekolah (RAPBS/RKAS); kriteria kinerja sekolah; kriteria fasilitas pendidikan di sekolah; dan kriteria kerja sama sekolah dengan pihak lain; (2) menggalang dana dan sumber dana pendidikan lainnya dari masyarakat, baik perorangan/organisasi/dunia usaha/dunia industri, maupun pemangku kepentingan lainnya melalui upaya kreatif dan inovatif; mengawasi pelayanan pendidikan di sekolah, sesuai dengan ketentuan, peraturan perundang-undangan; (4), menindaklanjuti, keluhan, saran, kritik, dan aspirasi dari peserta didik, orang tua/wali, dan masyarakat, serta hasil pengamatan komite sekolah atas kinerja sekolah (Peraturan Menteri Pendidikan dan Kebudayaan Nomor 75 Tahun 2016)

Uraian berkaitan dengan peran, fungsi dan tugas komite di atas harus menjadi konsentrasi dan bagian dari intervensi seluruh anggota komite sekolah untuk bersama-sama dengan tenaga pendidik dan kependidikan dalam membangun dan 
mengembangkan sekolah. Seperti diketahui, saat ini jumlah penduduk usia produktif lebih banyak dari usia tidak produktif. Dominasi jumlah penduduk usia produktif ini akan mencapai puncaknya, 70\% pada tahun 2020-2035. Untuk melahirkan SDM usia produktif agar menjadi sosok potensial yang bermanfaat bagi pembangunan diperlukan sinergitas komite sekolah dengan unsur sekolah dalam membangun dan mengembangkan sekolah sehingga dapat menjadi tempat penempaan setiap siswa. Berbagai langkah guna meningkatkan kualitas sumber daya manusia yang muaranya adalah menyejahterakan masyarakat harus terus dilakukan. Untuk itu, peran komite sekolah untuk bersama-sama dengan unsur sekolah dalam membangun dan mengembangkan pendidikan, mutlak diperlukan.

\section{SINERGITAS KOMITE SEKOLAH DENGAN SEKOLAH}

Secara etimologis, "hubungan masyarakat" diterjemahkan dari bahasa Inggris "public relation", yang berarti hubungan sekolah dengan masyarakat ialah sebagai hubungan timbal balik antara suatu organisasi (sekolah) dengan masyarakatnya. Istilah hubungan dengan masyarakat public relations dikemukakan pertama kali oleh presiden Amerika Serikat, Thomas Jefferson pada tahun 1807.
Menurut Kindred Leslie, dalam bukunya "School Public Relation" mengemukakan pengertian hubungan sekolah dengan masyarakat adalah: suatu proses komunikasi antara sekolah dengan masyarakat yang berusaha menanamkan kepada warga masyarakat tentang kebutuhan dari penyelenggaran pendidikan serta mendorong minat dan tanggung jawab masyarakat untuk memajukan sekolah". Sedangkan menurut Abdurrachman pengertian hubungan sekolah dengan masyarakat ialah kegiatan untuk menanamkan dan memperoleh pengertian, good will, kepercayaan, penghargaan dari publik sesuatu badan khususnya dan masyarakat pada umumnya (Suryosubroto, 2004:155).

Pengertian hubungan sekolah dengan masyarakat yang dikemukakan Kindred Leslie dan Abdurrachman di atas dapat disimpulkan bahwa hubungan sekolah dengan masyarakat adalah berkomunikasi sampai menimbulkan relasi, yang dapat membina partisipasi masyarakat dan menerima gagasan dan ajakan serta berusaha mensukseskannya. Prinsipprinsip dalam membina hubungan sekolah dengan masyarakat adalah: 1) Kerjasama harus dimodali dengan itikad baik untuk menciptakan citra baik tentang pendidikan; 2) Pihak masyarakat berperan serta membantu dan merealisasikan program sekolah, hendaknya menghormati dan mentaati 
ketentuan/peraturan yang diberlakukan di sekolah; 3) Segala saran yang berkaitan dengan kepentingan sekolah harus disalurkan melalui lembaga resmi yang bertanggung jawab dalam melaksanakannya (Komite Sekolah); 4) Peran serta masyarakat bersifat konstruktif, diberi kesempatan mempelajari dan memahami permasalahan serta cara pemecahannya bagi kepentingan dan kemajuan sekolah. Komite Sekolah bersifat mandiri, tidak mempunyai hubungan hierarkis dengan satun pendidikan maupun lembaga pemerintah lainya. Komite sekolah mewadahi dan menyalurkan aspirasi dan prakarsa masyarakat dalam melahirkan kebijakan dan program pendidikan sebagai peningkatan tanggung jawab dan peran aktif dari seluruh lapisan masyarakat dalam penyelenggaran pendidikan serta mampu menciptakan suasana yang kondusif di daerah. Untuk lebih memberikan pengaruh dan arah bagi perubahan sosial, maka 3 transformasi yang akan dikedepankan menurut Baidhawy (2005: 118) menjelaskan: 1) transformasi diri; 2) transformasi sekolah; 3) transformasi lingkungan sosial.

Komite sekolah sebagai transformasi diri dengan sekolah, yaitu menyangkut sikap dan prilaku individu terhadap keseluruhan kelompok/individu, etnik dan budaya yang berbasis pada stereotif, prasangka dan rasisme. Sekolah harus siap dengan adanya kritikan, baik menyangkut pelaksana di bidang pendanaan, pelaksana di bidang kelembagaan, dan pelaksana di bidang kurikulum, karena transformasi merupakan titik sentral dari inovasi pendidikan di sekolah yang menekankan prinsip-prinsip martabat kemanusiaan, keadilan, persamaan, kebebasan bertanggung jawab bagi pengembangan pendidikan di sekolah/madrasah.

Komite Sekolah sebagai Transformasi Sekolah yaitu dimana sekolah sebagai komunitas multikultural harus mampu mengelola keragaman sehingga sehingga sekolah yang bersangkutan hidup dalam keragaman itu sendiri. Multikulturalisme merupakan suatu sistem kepercayaan dan prilaku yang mengakui dan menghargai kehadiran kelompokkelompok yang beragam dalam organisasi dan masyarakat, memahami dan menilai perbedaan sosiokultural mereka dan mendorong agar tetap memberi kontribusi berkesinambungan dalam suatu kontek kebudayaan inklusif yang memberdayakan semua dalam organisasi atau masyarakat. Usaha dalam melakukan perubahan transformasi sekolah melalui dua paradigma: pertama, paradigma toleransi yang ditandai dengan penambahan muatan pembelajaran yang tidak mengubah asumsi-asumsi dan konseptualisasi mendasar tentang 
pendidikan. Kedua, Paradigma transformasi yang berupaya merestrukturisasi sekolah melalui proses berkesinambungan yang melibatkan seluruh aspek pendidikan, dari kurikulum hingga kebudayaan sekolah. Tujuan dari transformasi sekolah adalah persamaan dan egalitarianism.

Komite sekolah sebagai Transformasi Lingkungan Sosial Sekolah, yaitu lingkungan sosial yang inklusif bukan hanya sekedar kesadaran dan kepekaan terhadap kebudayaankebudayaan, dan ide -ide orang lain dalam memulai proses perubahan di sekolah, akan tetapi lebih menekankan pada pola sikap, nilai, kebiasaan dan keterampilan yang akan dikembangkan di masyarakat, mampu membuat keputusan, keterampilan tindakan sosial, kapabilitas kepemimpinan, dan komitmen moral pada martabat dan persamaan manusia.

Ketiga transformasi komite sekolah dalam pendidikan diatas, sebaiknya kita gunakan sebagai pedoman dan penguatan dalam membangun sinergitas komite sekolah dengan unsur sekolah. Sehingga tercipta sekolah yang berwawasan multikultural dengan mengedepankan sikap, nilai, kebiasaan dan keragaman etnis guna menghasilkan perubahan, dalam memanage sekolah.

\section{KESIAPAN KOMITE SEKOLAH DAN SEKOLAH ERA ABAD 21}

Perkembangan dan perjalanan dunia ini sudah berada di abad ke -21, dimana sudah tejadi banyak perubahan, termasuk dalam dunia pendidikan. Abad ke-21 dimulai dari tahun 2001, karena hitungan tahun semenjak ditemukannya kalender masehi, awal pada awal mula ditemukannya tahun seharusnya ada pada tahun nol, dan ulang tahun pertama harusnya ada pada tahun 1, makanya masuk tahun 2000 disebut sebagai abad ke - 21 (htt://id.answer.yahoo.com/questions).

Dengan demikian tahun 2017 ini sudah merupakan dasawarsa ke-2 pada abad ke-21; karena dasawarsa ke-1 sudah berlalu, yakni tahun 2000 - 2009. Abad ke - 21 ini sudah banyak dilihat gerakan pembaharuan standarisasi kebutuhan pendidikan termasuk perubahan masyarakat modern merupakan suatu keharusan.

Menurut Tilaar (2012) di abad ke21 ini peradaban sudah semakin maju, demikian pula adanya dengan pendidikan; dunia semakin terbuka, kegiatan semakin modern bahkan menuju kearah globalisasi. Kehidupan juga semakin materialistis dan masyarakat semakin konsumtif serta menghargai hal-hal yang bersifat duniawi. Kehidupan sudah semakin luas dan terbuka di dalam dunia tanpa batas. Kualitas sumber daya manusia yang diperoleh melalui pendidikan dan 
pelatihan adalah merupakan kebutuhan dari manusia di abad ini. Di era ini, pendidikan adalah suatu yang dipaksakan dan merupakan suatu ranah bisnis, masyarakat berupaya mendirikan lembaga-lembaga pendidikan dalam rangka menghimpun materi, namun tetap berupaya meningkatkan kualiats pendidikan melalui sekolah yang dididirikannya. Hal ini tentu juga masih sesuai dengan tuntutan reformasi pendidikan yang menginginkan perubahan ke arah yang lebih baik.

Terkait dengan pemanfaatan teknologi informasi dan komunikasi (Information and Communication Technology / ICT) di dunia pendidikan, telah mengakibatkan semakin meleburnya dimensi "ruang dan waktu" yang selama ini menjadi faktor penentu kecepatan dan keberhasilan penguasaan manusia terhadap ilmu dan teknologi. Di Abad-21 ini kita ditantang untuk mampu menciptakan pendidikan yang dapat menghasilkan sumber daya pemikir yang mampu ikut membangun tatanan sosial dan ekonomi sadar pengetahuan sebagaimana layaknya warga dunia di Abad-21. Tentu saja dalam memandang ke depan dan merancang langkah kita tidak boleh berpaling dari kenyatan yang mengikat kita dengan realita kehidupan.

Berbagai upaya dalam rangka peningkatan mutu pendidikanpun senantiasa dilakukan, disesuaikan dengan perkembangan situasi dan kondisi, serta era yang terjadi. Dalam konteks pendidikan di Abad ke-21 ini ada pihak-pihak yang menyikapinya sebagai sebuah peluang, namun ada juga yang memandangnya sebagai tantangan atau hambatan, tergantung dari kemampuan serta cara pandang masing-masing. Banyak fenomena penting terkait dengan pendidikan di Abad ke-21, yang dapat kita saksikan. Beberapa di antaranya adalah: 1) Globalisasi dan Pendidikan Globalisasi berawal dari niat negara-negara industri maju untuk menghasilkan produkproduk yang memiliki nilai tambah tinggi dengan muatan ilmu dan teknologi mutakhir, 2) Budaya dan Karakter Bangsa, 3) Budaya Internet dan Cyber Society.

Oleh karena itu, ada anggapan bahwa generasi Abad-21 tidak boleh gagap dalam 3 hal, yaitu: gagap teknologi (gaptek), gagap internet (gapnet), dan gagap terhadap block (gap block).Konvergensi antara internet dengan komunikasi selular (mobile phone) yang disertai oleh semakin tinggi dan canggihnya kapasitas operasionalnya, kemudian didukung oleh berbagai inovasi perangkat keras yang semakin menubuh dengan diri kita, maka suka atau tidak, internet mulai menggantikan model komunikasi kehidupan sosial (ekonomi, politik, budaya), dan bahkan dapat mengubah sistem dan nilai budaya serta dimensi 
spiritual, berikut dengan implikasi baik buruknya. (BSNP, 2010: 26-27)

Terkait dengan pendidikan telah di tetapkan dalam Undang-Undang Nomor 20 Tahun 2003 tentang Sistem Pendidikan Nasional, pada pasal 1 angka 1 dinyatakan bahwa pendidikan adalah usaha sadar dan terencana untuk mewujudkan suasana belajar dan proses pembelajaran agar peserta didik secara aktif mengembangkan potensi dirinya untuk memiliki kekuatan spiritual keagamaan, pengendalian diri, kepribadian, kecerdasan, akhlak mulia, serta keterampilan yang diperlukan dirinya, masyarakat, bangsa, dan negara.

Pertanyaannya adalah: Dengan munculnya berbagai fenomena pendidikan di Abad ke-21 ini, mampukah mampukah masyarakat, sekolah dan pemerintah mencapai tujuan/cita-cita luhur yang telah ditetapkan dalam Undang-Undang dan berbagai peraturan pemerintah ? Tentunya tidak mustahil kita mampu, manakala kita memiliki sumberdaya manusia (SDM) yang kompeten dibidangnya. Namun jika SDM yang kita miliki kurang memiliki kompetensi yang memadai, maka potensi itu justru akan menjadi beban berat luar biasa bagi daerah bahkan negara.

Maka langkah tepat dan cepat perlu diambil untuk menjamin terbentuknya generasi yang kompeten sesuai dengan tuntutan perkembangan, salah satunya adalah semua pihak (masyarakat, sekolah dan pemerintah) melakukan kerja sama tanpa batas waktu dan ruang.

Terkait dengan itu, paradigma pendidikan yang demokratis, bernuansa permainan, penuh keterbukaan, menantang, melatih rasa tanggung jawab, akan merangsang anak didik untuk datang ke sekolah atau ke kampus karena senang, bukan karena terpaksa. Meminjam kata-kata Ackoff \& Greenberg (2008): “Education does not depend on teaching, but rather on the selfmotivated, curiosity and selfinitiated actions of the learner."

Ada 8 persiapan yang harus diiplementasikan oleh pemerintah, sekolah dan masyarakat, yaitu: (1) Untuk menghadapi di Abad ke-21 yang makin syarat dengan teknologi dan sains dalam masyarakat global di dunia ini, maka pendidikan kita haruslah berorientasi pada matematika dan sains disertai dengan sains sosial dan kemanusiaan (humaniora) dengan keseimbangan yang wajar; Pendidikan bukan hanya membuat seorang peserta didik berpengetahuan, melainkan juga menganut sikap keilmuan dan terhadap ilmu dan teknologi, yaitu kritis, logis, inventif dan inovatif, serta konsisten, namun disertai pula dengan kemampuan beradaptasi; (3) Mulai dari pendidikan anak usia dini, pendidikan dasar, menengah dan pendidikan tinggi haruslah merupakan 
suatu sistem yang tersambung erat tanpa celah, setiap jenjang menunjang penuh jenjang berikutnya, menuju ke frontier ilmu. Namun demikian, terbuka pula jenjang untuk langsung terjun ke masyarakat; (4) Pada setiap jenjang pendidikan perlu ditanamkan jiwa kemandirian, karena kemandirian pribadi mendasari kemandirian bangsa, kemandirian dalam melakukan kerjasama yang saling menghargai dan menghormati, untuk kepentingan bangsa; (5) Khusus di perguruan tinggi, dalam menghadapi konvergensi berbagai bidang ilmu dan teknologi, maka perlu dihindarkan spesialisasi yang terlalu awal dan terlalu tajam; (6) Dalam pelaksanaan pendidikan perlu diperhatikan kebhinnekaan etnis, budaya, agama dan sosial, terutama di jenjang pendidikan awal; (7) Seluruh warganegara dapat mengenyam pendidikan sampai ke jenjang pendidikan yang sesuai dengan kemampuannya, pada dasarnya pendidikan harus dilaksanakan oleh pemerintah dan masyarakat dengan mengikuti kebijakan yang ditetapkan oleh pemerintah (pusat dan daerah), (8) Untuk menjamin terlaksananya pendidikan yang berkualitas, sistem monitoring yang benar dan evaluasi yang berkesinambungan perlu dikembangkan dan dilaksanakan dengan konsisten (BSNP, 2010: 43)

Uraian di atas, membutuhkan sejumlah prasyarat di mana semua pihak perlu memiliki komitmen, memahami berbagai permasalahan terkait dengan berbagai tantangan pendidikan di Abad ke-21, memiliki sarana dan prasarana pendukung yang memadai, serta mampu dan mau memanfaatkan ilmu dan teknologi yang tersedia. Dalam abad 21 terdapat berbagai kekhususan yaitu terwujudnya masyarakat global yang menjadi kesepakatan antara bangsa, terbukanya mobilitas yang lebih luas antara satu negara dengan negara lain dalam berbagai hal. Dalam abad ini masingmasing stakeholder pendidikan tidak lagi bekerja sendiri, melainkan saling bekerja sama, bukan hanya dalam sesama kelompok sekolah saja, melainkan dalam lintas sekolah. Dengan demikian rangkaian setiap jenjang pendidikan, mulai jenjang Pendidikan Anak Usia Dini (PAUD) sampai dengan jenjang pendidikan tinggi, harus saling membahu dengan ciri khasnya tersambung secara utuh.

Rekonstruksi citra bangsa baru akan terlihat jika kita ikut berlomba dalam peradaban dengan menyumbangkan karya dan pikiran dalam tatanan dunia yang baru. Semua Usaha untuk kepentingan dan keselarasan pembangunan bangsa menghadapi ekonomi dan sosial yang sadar pengetahuan yang tidak hanya mengagungkan satu alur pemikiran saja. Berbagai Negara di dunia berusaha untuk mendefinisikan karakteristik 
masyarakat abad ke-21 berdasarkan " $21^{\text {st }}$ Century Partnership Learning Framework", terdapat beberapa kompetensi atau keahlian yang harus dimiliki oleh SDM abad 21, yaitu: (1) Kemampaun berpikir kritis dan pemecahan masalah (CriticalThinking and Problem-Solving Skills), terutama dalam konteks pemecahan masalah;

Kemampuan berkomunikasi dan bekerjasama (Communication and Collaboration Skills) berkolaborasi secara efektif dengan berbagai pihak; (3) Kemampuan mencipta dan membaharui (Creativity and Innovation Skills), yakni mampu mengembangkan kreativitas yang dimilikinya untuk menghasilkan berbagai terobosan yang inovatif, (4) Literasi teknologi informasi dan komunikasi (Information and ommunications Technology Literacy) yakni mampu memanfaatkan teknologi informasi dan komunikasi untuk meningkatkan kinerja dan aktivitas sehari-hari (Seels \& Richey, 1994)

Dengan ditemukan dan dikembangkannya internet sebuah jejaring raksasa yang menghubungkan milyaran pusat-pusat data/informasi di seluruh dunia dan individu/komunitas global telah merubah proses pencarian dan pengembangan ilmu dalam berbagai lembaga pendidikan. Proses tukar menukar pengetahuan dan kolaborasi antar siswa dan guru di seluruh dunia akan lebih mudah untuk meningkatkan kualitas kehidupan manusia. Dengan mudahnya akses terhadap berbagai pusat pembelajaran melalui pemanfaatan teknologi informasi dan komunikasi, maka peran guru/dosen dan peserta didik pun menjadi berubah. Kalimat "the world is my class" mencerminkan bagaimana seluruh dunia beserta isinya ini menjadi tempat manusia pembelajar meningkatkan pengetahuan dan kompetensinya, dalam arti kata bahwa proses pencarian ilmu tidak hanya berada dalam batasan dinding-dinding kelas semata. Peran guru pun tidak lagi menjadi seorang "infomediary" karena peserta didik sudah dapat secara langsung mengakses sumber-sumber pengetahuan yang selama ini harus diseminasi atau didistribusikan oleh guru/dosen di kelas. Guru akan lebih berfungsi sebagai fasilitator, pelatih ("coach"), dan pendamping para siswa yang sedang mengalami proses pembelajaran. Di samping itu, penyelenggaraan kegiatan belajar mengajar pun harus diperluas melampaui batas-batas ruang kelas, dengan cara memperbanyak interaksi siswa dengan lingkungan sekitarnya dalam berbagai bentuk metodologi. Berpegang pada prinsip bahwa setiap individu itu unik dan memiliki talentanya masing-masing, maka metode belajar mengajar pun harus memperhatikan keberagaman "learning style" dari masing-masing individu. 
Oleh karena itu di sekolah model belajar yang menekankan pada ciri khas dan keberagaman ini perlu dikembangkan, seperti misalnya yang diperkenalkan dalam: PBL (Problem Based Learning), PLP (Personal Learning Plans), PBA (Performance Based Assessment). dan model pembelajaran berbasis kerjasama antar individu seperti dalam konsep: Cooperative Learning, Collaborative Learning, dan Meaningful Learning. Tugas utama guru adalah memastikan bahwa melalui mekanisme pembelajaran yang dikembangkan, setiap individu dapat mengembangkan seluruh potensi diri yang dimilikinya untuk menjadi manusia pembelajar yang berhasil.

\section{STRATEGI}

PENCAPAIAN

PENDIDIKAN DI SEKOLAH ABAD KE-21

Strategi pencapaian Pendidikan di sekolah abad ke-21 dalam keanekaragaman geo-demografis, budaya, dan memperhatikan tantangan global dan lokal tentang budaya sebagai karakter bangsa, serta adanya potensi, semua stakeholder (sekolah, masyarakat dan pemerintah) memegang tanggung jawab penuh terkait dalam menentukan kebijakan dan kemauan politik untuk menghadapi tantangan perubahan paradigma. Strategi pendidikan meliputi pelaksanaan operasional untuk mencapai sasaran paradigma yaitu: (a) Menumbuhkan komitmen; meningkatkan pemberdayaan melalui tugas dan fungsi masing-masing; (b) Meningkatkan keterlibatan sektor informal dan lembaga swadaya masyarakat terutama dalam pendidikan nonformal maupun informal sesuai dengan paradigm baru;

Menumbuhkan dan meningkatkan kreativitas inovatif masyarakat dalam pengembangan dan pelaksanaan paradigma yang sesuai dengan budaya setempat; (d) Menumbuhkan dan meningkatkan sumber daya manusia bidang pendidikan yang mengacu pada implementasi paradigma; Meningkatkan dan pemeratakan keberadaan pendidikan formal, serat nonformal sesuai dengan kebutuhan masyarakat dan potensi pengembangan daerah masing-masing.

Strategi pencapaian tujuan pendidikan di sekolah yang diuraikan di atas, merupakan pendidikan di sekolah berbasis perubahan paradigma yang meliputi perencanaan dan pelaksanaan input, proses dan target luaran yang akan dicapai oleh sekolah. Adapun prinsip pokok implementasinya adalah: (1) Instruction should be studentcentered (pembelajaran yang berpusat pada siswa); (2) Education should be collaborative berkolaborasi (pembelajaran berkolaborasi dengan orang lain); (3) Learning should have context (materi pelajaran perlu dikaitkan dengan kehidupan sehari-hari siswa); (4) Schools should be integrated with society 
(mempersiapkan siswa menjadi warga negara yang bertanggung jawab untuk terlibat dalam lingkungan sosialnya) (Jennifer Nichols, 2015)

Dengan memperhatikan uraian di atas, maka kesuksesan itu memiliki kunci yang mutlak Yaitu memiliki interaksi di masyarakat, ada kerjasama dan kolaborasi di masyarakat. Sumber daya merupakan "produk" dari pendidikan di suatu bangsa. Untuk menghasilkan sumber daya manusia dengan multi kompetensi, sekolah terutama guru sebagai "sutradara lapangan" dituntut untuk 'mengubah' cara menyelenggarakan pendidikan dengan cara yang berbeda dengan caracara yang selama ini telah dijalankan. Guru dituntut untuk benar-benar profesional dalam dalam mengemban tugas dan fungsinya sebagai sosok pengajar dan pendidik dengan berbekal kompetensi paedagogik, kepribadian, sosial dan profesional secara utuh.

Pemerintah dituntut tidak "asalasalan" dalam rekrutmen guru-guru. Tetapi guru yang mampu berpikir kritis, kompeten dalam memecahkan masalah, kreatif-inovatif, komunikatif, menguasai ilmu pengetahuan, menguasai multi bahasa dan menguasai ICT. Didukung dengan kompetensi kepribadian, emosional dan spiritual yang stabil. Penerapan MBS bisa disebut suatu pergeseran paradigma dalam pengelolaan pendidikan. MBS bermaksud "mengembalikan" sekolah kepada pemiliknya yaitu masyarakat, yang diharapkan akan merasa bertanggung jawab kembali sepenuhnya terhadap pendidikan yang diselenggarakan di sekolah-sekolah. Dalam penyelenggaraan pendidikan, masyarakat mendapat kesempatan yang seluas-luasnya untuk berpartisipasi dalam pengelolaan satuan pendidikan pada berbagai jenis dan jenjang (Surya Mohamad, 2002).

Untuk penyelenggaraan pendidikan di sekolah, konsep masyarakat disederhanakan (simplified) sehingga mudah bagi sekolah melakukan hubungan dengan masyarakat. Penyederhanaan konsep masyarakat itu dilakukan melalui "perwakilan" fungsi stakeholder, dengan jalan membentuk Komite Sekolah. Komite Sekolah sedapat mungkin bisa mempresentasikan keragaman yang ada agar benar-benar dapat mewakili masyarakat. Bukti tanggung jawab masyarakat terhadap pendidikan diwujudkan dalam fungsi yang melekat pada Komite Sekolah (Ace Suryadi dkk, 2004).

\section{SIMPULAN}

Rekonstruksi hubungan komite sekolah dan sekolah era pendidikan abad ke-21merupakan suatu keharusan, mengingat setelah lebih dari tiga belas tahun terbitnya kebijakan terkait dengan komite sekolah, yakni sejak dikeluarkannya Keputusan Menteri 
Pendidikan Nasional Nomor 044/U/2002 tentang Dewan Pendidikan dan Komite Sekolah dan Peraturan Pemerintah Nomor 17/2010 tentang Pengelolaan dan Penyelenggaraan Pendidikan. Keberadaan komite sekolah di sebagian besar sekolah mulai dari jenjang PAUD sampai jenjang menengah atas masih belum menujukan kinerja sebagai mitra dan pendamping sekolah dalam mewujudkan capaian peningkatan mutu pendidikan. Walaupun ada, itupun sebagian kecil dari sekolah dan komite sekolah.

Oleh karena itu, sekolah pada semua jenjang dan tingkatan harus memberi ruang yang luas kepada Komite Sekolah sesuai peran, fungsi dan tugas sebagaimana yang telah diatur dalam undang-undang dan peraturan pemerintah yang berlaku. Peran komite sekolah sebagai pendukung penyelenggaraan pendidikan di sekolah (supporting) dilakukan dalam bentuk dukungan finansial, bantuan pemikiran atau gagasan, maupun tenaga atau keahlian. Peran komite sekolah terkait dengan pengawasan penyelenggaraan sekolah terhadap komponen sistem (input, proses, output), terutama pada komponen proses dan output sekolah. Peran pengawasan (controlling) terhadap penyelenggaraan pendidikan di sekolah. Untuk itu, peran komite sekolah ini harus dikembalikan kepada komite sekolah. Sekolah harus membuka diri, untuk menjamin bahwa menyelenggarakan pendidikan di sekolah dengan prinsip transparan, akuntabel dan memiliki komitmen tinggi terhadap pencapaian mutu yang tinggi.

Demikian halnya dengan pemerintah dari pusat sampai ke daerah untuk melakukan pembinaan terhadap Komite Sekolah agar kinerja Komite Sekolah dapat ditingkatkan. Pembinaan dapat dilakukan oleh jajaran Dinas Pendidikan Nasional, Dewan Pendidikan, maupun LSM yang bergerak bidang pendidikan. Dengan demikian hubungan masyarakat dengan sekolah (Public Relations) akan terjalinan dengan kondusif. Di era pendidikan abad ke-21 saat ini, semua organisasi termasuk komite sekolah dituntut untuk terus menerus mempersiapkan dirinya mengantisipasi dan menyesuaikan diri dengan perubahan. Kerja sama lintas organisasi merupakan "kunci kesuksesan". Hanya dengan kerjasama semua pihak pada adad ke-21 mampu mempersiapkan dan menghadapi arus globalisasi yang menuntut sejumlah keterampilan yaitu: (1) melek visual, melek ilmiah, melek teknologi, melek informasi, melek budaya, dan memiliki kesadaran global; (2) memiliki kemampuan berpikir penemuan (kreatif dan inovatif); (3) memiliki kemampuan berpikir tingkat tinggi dan rasional; (4) memiliki kemampuan berkomunikasi yang efektif, keterampilan interpersonal, mampu dan mau bekerja sama 
(kolaboratif), memiliki tanggung jawab personal dan sosial; (5) memiliki produktivitas yang tinggi, tindakannya konstruktif, percaya pada diri sendiri dan tanggung jawab.

\section{DAFTAR PUSTAKA}

Ace, Suryadi dkk,. 2004. Pembelajaran Terkini: Perpaduan Indonesia Malaysia. Yogyakarta: Pustaka Belajar.

Ackoff, Greenberg. 2008. A new assessment era: Different needs new challenges. Learning and Instruction, 10, 11-20.

Baidhawy. 2005. Tujuan Pendidikan Holistik Mengenai Tujuan Pendidikan Nasional. Jakarta: PT Pradnya Paramita.

Badan Standar Nasional Pendidikan. 2010. Paradigma Pendidikan Nasional Di Abad-21. Jakarta: BSNP

http://id.answer.yahoo.com/questions.20 $\underline{18}$

Mulyasa, E. 2002. Manajemen Berbasis Sekolah Konsep, Strategi dan Implementasi. Bandung: Remaja Rosdakarya.

Kemendiknas. 2002. Lampiran Surat Keputusan Menteri Pendidikan Nomor 044/U/2002 tentang Dewan
Pendidikan dan Komite Sekolah. Jakarta: Depdiknas

Permendiknas. 2016. Peraturan Menteri Pendidikan dan Kebudayaan Nomor 75 Tahun 2016 tentang Kinerja komite Sekolah. Jakarta: Depdiknas Undang-Undang . 2003. Undang-Undang Republik Indonesia nomor 20 Tahun 2003 tentang Sistem Pendidikan Nasional. Jakarta: Depdiknas

Undang-Undang Nomor 25 Tahun 1999. Tentang Program Pembangunan Nasional (PROPENAS) 2000-2004 dan Undang-Undang Nomor 32 Tahun 2004 tentang otonomi daerah. Jakarta.

Tilaar. 2012. Pendidikan Indonesia: Harapan, Visi, dan Strategi. Jogjakarta: Pustaka Pelajar.

Suryosubroto. 2004. Tujuan Pendidikan Holistik Mengenai Tujuan Pendidikan Nasional. Jakarta: PT Pradnya Paramita

Seels, Richey. 1994. Models of teaching, 5th edition. Boston: Allyn Bacon.

Surya, Mohamad. 2002. Asesmen Kebutuhan Penerapan Manajemen Berbasis Pengetahuan dalam Pembangunan Pendidikan Daerah", dalam Cakrawala Pendidikan, XXXII (2), hlm. 220-230. 